\title{
Developmental Changes in the Kinetics of Glucose and Urea in Holstein Calves
}

\author{
H. Hayashi,, ${ }^{\star 1}$ M. Kawai, ${ }^{\star}$ I. Nonaka,† F. Terada,† K. Katoh, ${ }^{\star}$ and Y. Obara* \\ ${ }^{*}$ Department of Animal Physiology, Graduate School of Agricultural Science, Tohoku University, \\ Tsutsumidori, Aoba-ku, Sendai, 981-8555, Japan \\ †Department of Animal Physiology and Nutrition, National Institute of Livestock and Grassland Science, \\ 2 Ikenodai, Tsukuba City, Ibaraki, 305-0901, Japan
}

\begin{abstract}
Because weaning is the point when the nutrient composition of feed changes for the neonatal ruminant, the present experiment was conducted to assess the developmental changes in the kinetics of glucose and urea over this period, using stable isotopes of glucose and urea, at 4, 13, and 24 wk in calves. Plasma concentrations of nonesterified fatty acids, amino-N, urea-N, and insulin-like growth factor-I increased, but that of growth hormone decreased with age. The plasma glucose concentration increased at $13 \mathrm{wk}$ of age and thereafter decreased at $24 \mathrm{wk}$ of age. The glucose irreversible loss and recycling rates were significantly higher at 4 wk of age than at 13 and 24 wk of age. On the other hand, the irreversible loss and recycling rates of urea, as well as the urea pool size, were higher at $24 \mathrm{wk}$ of age than at 4 and 13 wk. It is concluded that weaning at $6 \mathrm{wk}$ is the pivotal time for the alteration of glucose kinetics. However, the aging process, but not weaning, is important for changes in the kinetics of urea in calves. Key words: glucose kinetics, urea kinetics, aging, calf
\end{abstract}

\section{INTRODUCTION}

Although newborn ruminants digest ingested milk in the abomasum before weaning, they begin to have a symbiotic relationship with bacteria that develops along with the morphological structure of the rumen after weaning. With the development of the rumen, dietary carbohydrates are fermented to produce shortchain fatty acids by the anaerobic activities of rumen microbes. These short-chain fatty acids are absorbed across the rumen epithelium as the animal's main source of energy (Annison and Armstrong, 1969). Accordingly, glucose absorbed by the small intestine decreases (Huntington and Reynolds, 1986), and most of the glucose needs of the ruminant must be met from

Received June 28, 2005.

Accepted November 15, 2005.

${ }^{1}$ Corresponding author: hhayashi@rakuno.ac.jp gluconeogenesis (Wolff and Bergman, 1972). It is thought that this glucose is mainly recycled via the Cori cycle. In addition, the glucose turnover rate and recycling rate decrease after weaning in sheep (Muramatsu et al., 1974) but do not change in cattle during the period of growth after weaning (Russell et al., 1986).

It has been assumed that the reticulorumen is the principal site for the appearance of recycled urea in the digestive tract, and that a large quantity of urea is transferred to the rumen. In the ruminant, an increase in the $\mathrm{N}$ content in feeds increases the plasma urea concentration, urea turnover rate, and the urea concentration in saliva (Ide, 1975; Obara and Shimbayashi, 1980). In addition, the secretion of metabolic hormones, such as growth hormone (GH) or insulin, changes greatly around weaning (Katoh et al., 2004a). Although there are reports on the turnover and recycling of urea (Obara and Dellow, 1994) and glucose (Russell et al., 1986) in adult ruminants, developmental changes in glucose and urea kinetics, particularly around weaning, are poorly understood.

It was demonstrated that the weaning of calves and goats reduces the expression of the sodium-dependent glucose transporter 1 and CD36 (a fatty acid transporter; Hayashi et al., 2004, 2005) as well as leptin (Yonekura et al., 2002) in the gastrointestinal tract. The salivary secretion rate (Sasaki, 1968) and the activity of carbonic anhydrase in the parotid gland (Kitade et al., 2002) in calves are increased around weaning. Also, salivary urea level was almost $60 \%$ of the plasma urea level (Obara and Shimbayashi, 1980). It was thought from these results that the urea transfer rate to the rumen via saliva was increased around weaning.

Therefore, it was hypothesized that the rumen development around weaning would dramatically change urea and glucose kinetics. The aim of the current experiment was to assess the developmental changes in glucose and urea kinetics in pre- (4-wk old) and postweaning (13- and 24-wk-old) calves.

\section{MATERIALS AND METHODS}

The present experiment was conduced according to the "Guiding Principles for the Care and Use of Animals 
Table 1. Composition of rations given to the calves at 4, 13, and 24 wk of age

\begin{tabular}{|c|c|c|c|}
\hline \multirow[b]{2}{*}{ Ingredient } & \multicolumn{3}{|c|}{ Component, \% of DM } \\
\hline & $4 \mathrm{wk}$ & $13 \mathrm{wk}$ & $24 \mathrm{wk}$ \\
\hline Milk replacer & 100 & - & - \\
\hline Timothy & - & 19.52 & - \\
\hline Italian ryegrass & - & - & 27.11 \\
\hline Alfalfa hay cube & - & - & 12.23 \\
\hline Alfalfa meal & - & 10.31 & - \\
\hline Barley & - & 35.68 & 51.66 \\
\hline Corn & - & 14.74 & - \\
\hline Soybean meal & - & 10.53 & 8.58 \\
\hline Calcium linoleate & - & 4.31 & - \\
\hline Brown rice & - & 3.92 & - \\
\hline Calcium phosphate & - & 0.65 & - \\
\hline Calcium carbonate & - & - & 0.40 \\
\hline $\mathrm{NaCl}$ & - & 0.28 & - \\
\hline Vitamin $\mathrm{A}, \mathrm{D}$, and $\mathrm{E}$ premix & - & 0.06 & 0.02 \\
\hline DM fed, g/d & 733 & 2,211 & 3,980 \\
\hline $\mathrm{ME}, \mathrm{Mcal} / \mathrm{d}$ & 3.1 & 6.7 & 11.5 \\
\hline $\mathrm{CP}, \mathrm{g} / \mathrm{d}$ & 187 & 320 & 622 \\
\hline
\end{tabular}

in the Field of Physiological Sciences" (The Physiological Society of Japan), and was approved by The Animal Care Committee of Tohoku University.

\section{Animals and Diet Components}

Fifteen Holstein calves at 4 wk (before weaning), and 13 and 24 wk of age (after weaning) were used. Calves were fed colostrum after birth for $3 \mathrm{~d}$ and milk replacer (Calf Top, Zenrakuren, Tokyo, Japan) afterwards. Calves were fed concentrated feed from 4 wk of age and weaned at 6 wk of age. Calves were fed according to the Japanese Feeding Standard (AFFRC, 1999), which is designed to meet the requirements for energy. The feed amount was based on BW and reassessed weekly. At the time of the experiment, calves were fed 680 (4 wk), 2,211 (13 wk), and 3,980 g/d of DM (24 wk), respectively (Table 1 ). To be able to approach a steady state, feeding frequency was planned using a method modified from Sutoh et al. (1993) and Sutton et al. (1988). Calves at $4 \mathrm{wk}$ of age $(\mathrm{n}=4)$ were fed milk alone divided into 6 meals daily (fed every $4 \mathrm{~h}$ from $0900 \mathrm{~h}$ ). Calves at 13 $(\mathrm{n}=5)$ and $24(\mathrm{n}=6)$ wk of age were fed 12 meals daily (fed every $2 \mathrm{~h}$ from $0900 \mathrm{~h}$ ) via a continuous feeder. The experiment used different calves in each week of age. All calves had ad libitum access to water.

\section{Experimental Design}

Calves were fed the appropriate rations, as outlined in Table 1, for at least $2 \mathrm{wk}$ before the experiment as well as during the experiment. On the day before the first day of the experiment, polyethylene catheters were inserted into both jugular veins and were kept filled with physiological saline $(0.9 \% \mathrm{NaCl})$ containing heparin (200 units/mL).

Single Injection of Labeled Glucose. At $1000 \mathrm{~h}$ on the day of the experiment, an injection of glucose solution was administered into the jugular vein. The glucose solution contained $\left[\mathrm{U}_{-}{ }^{13} \mathrm{C}\right] \mathrm{D}$-glucose $(98.5$ atom percent; Shoko, Tokyo, Japan) and $\left[6,6-{ }^{2} \mathrm{H}_{2}\right] \mathrm{D}$-glucose (99 atom percent; Cambridge Isotope Laboratories, Andover, MA) in $15 \mathrm{~mL}$ of saline. The quantity of labeled glucose was $20 \mathrm{mg}$ of $\left[\mathrm{U}_{-}{ }^{13} \mathrm{C}\right] \mathrm{D}-\mathrm{glucose}$ and $0.7 \mathrm{~g}$ of $[6,6-$ $\left.{ }^{2} \mathrm{H}_{2}\right] \mathrm{D}$-glucose at $4 \mathrm{wk}$ of age, $40 \mathrm{mg}$ of $\left[\mathrm{U}^{13}{ }^{13} \mathrm{C}\right] \mathrm{D}$-glucose and $1.5 \mathrm{~g}$ of $\left[6,6-{ }^{2} \mathrm{H}_{2}\right] \mathrm{D}$-glucose at $13 \mathrm{wk}$ of age, and 72 $\mathrm{mg}$ of $\left[\mathrm{U}_{-}{ }^{13} \mathrm{C}\right] \mathrm{D}$-glucose and $1.5 \mathrm{~g}$ of $\left[6,6-{ }^{2} \mathrm{H}_{2}\right] \mathrm{D}$-glucose at $24 \mathrm{wk}$ of age. Blood samples were taken from the opposite jugular vein at $-10,-5,5,10,15,30,45,60$, $90,120,150,180,240$, and $300 \mathrm{~min}$ after injection. Blood samples were immediately transferred to tubes containing heparin, and centrifuged at $8,000 \times g$ for $20 \mathrm{~min}$ at $4^{\circ} \mathrm{C}$. Plasma samples were stored at $-30^{\circ} \mathrm{C}$ until analysis.

Single Injection of Labeled Urea. On the day following single injection of labeled glucose, an injection of urea solution was administered into the jugular vein at $1000 \mathrm{~h}$. The urea solution contained $\left[{ }^{13} \mathrm{C}\right]$ urea (99 atom percent; Phenome Sciences, Woburn, MA) and $\left[{ }^{15} \mathrm{~N},{ }^{15} \mathrm{~N}\right]$ urea (99.6 atom percent; Shoko) in $15 \mathrm{~mL}$ of saline. The quantity of labeled urea was $55 \mathrm{mg}$ of $\left[{ }^{13} \mathrm{C}\right]$ urea and $55 \mathrm{mg}$ of $\left[{ }^{15} \mathrm{~N},{ }^{15} \mathrm{~N}\right]$ urea at $4 \mathrm{wk}$ of age, $110 \mathrm{mg}$ of $\left[{ }^{13} \mathrm{C}\right]$ urea and $110 \mathrm{mg}$ of $\left[{ }^{15} \mathrm{~N},{ }^{15} \mathrm{~N}\right]$ urea at $13 \mathrm{wk}$ of age, and $200 \mathrm{mg}$ of $\left[{ }^{13} \mathrm{C}\right]$ urea and $200 \mathrm{mg}$ of $\left[{ }^{15} \mathrm{~N},{ }^{15} \mathrm{~N}\right]$ urea at $24 \mathrm{wk}$ of age. Blood samples were taken at $-10,-5,10,20,30,60,90,120,180,240,300,360$, 480 , and $600 \mathrm{~min}$ after the injection, centrifuged as before, and stored at $-30^{\circ} \mathrm{C}$ until analysis.

\section{Sample Analyses}

Plasma concentrations of glucose, NEFA, and urea$\mathrm{N}$ were determined using commercially available kits (Wako Pure Chemical Industries, Osaka, Japan). Plasma concentrations of $\alpha$-amino-N were determined using the method described by Lee and Takahashi (1966). Plasma GH concentrations were measured by radioimmunoassay as described previously (Katoh et al., 2004a,b). Ovine GH and antibody were provided by the National Institute of Diabetes and Digestive and Kidney Diseases (NIDDK, Bethesda, MD). The minimum detectable level of GH was $0.1 \mathrm{ng} / \mathrm{mL}$. Intra- and interassay coefficients of variation were 5.9 and $6.8 \%$, respectively. Plasma IGF-I concentrations were measured in duplicate by radioimmunoassay using antiIGF-I rabbit serum (NIDDK, UBK 478). The assay was performed as previously described (Sakurai et al., 2004). The minimum detectable level of IGF-I was 0.1 
$\mathrm{ng} / \mathrm{mL}$. Intra- and interassay coefficients of variation were 10.9 and $13.6 \%$, respectively.

Samples for the measurement of the enrichment of $\left[6,6-{ }^{2} \mathrm{H}_{2}\right] \mathrm{D}$-glucose were prepared using a method modified from Wiecko and Sherman (1976) as described by Rose et al. (1996) and determined using a GLC connected to a mass spectrometry system (JMS-SX 102A, Nihon Denshi, Tokyo, Japan). The measurement of the enrichment of $\left[\mathrm{U}_{-}{ }^{13} \mathrm{C}\right] \mathrm{D}$-glucose was performed using a method described by Sano et al. (1996) using a GLCmass spectrometric system (M-2000, Hitachi, Tokyo, Japan). The measurement of the enrichment of $\left[{ }^{13} \mathrm{C}\right]$ urea and $\left[{ }^{15} \mathrm{~N},{ }^{15} \mathrm{~N}\right]$ urea was performed by the following methods. Blood plasma samples $(15 \mathrm{~mL})$ were deproteinized by the addition of $3 \mathrm{~mL}$ of $20 \%$ sulfosalicylic acid and $180 \mu \mathrm{L}$ of $6 \mathrm{~N} \mathrm{HCl}$, and the supernatant was collected after centrifugation $(8,000 \times g, 20 \mathrm{~min})$. The urea fraction was separated from the supernatant using $2 \mathrm{~mL}$ of cation exchange resin (AG 50W-X8 100200 mesh $\mathrm{H}^{+}$form, BioRad Laboratories, Hercules, CA) in a column. The urea fraction samples were then freeze-dried before analysis. The isotopic enrichment of $\left[{ }^{13} \mathrm{C}\right]$ urea and $\left[{ }^{15} \mathrm{~N},{ }^{15} \mathrm{~N}\right]$ urea were determined using a mass spectrometer, EA/IR-MS (DELTA plus, Finnigan MAT, ThermoQuest, San Jose, CA).

\section{Calculations}

Plasma concentrations of metabolites and metabolic hormones at the steady state remain stable by feeding (Sutton et al., 1988; Sutoh et al., 1993). Therefore, these values are shown as the mean in this study.

Figure 1 depicts the representative transition of atom percent excess of ${ }^{2} \mathrm{H}$ - (panel A) and ${ }^{13} \mathrm{C}$ - (panel B) glucose in plasma after the injection of the isotopes. The glucose pool size, irreversible loss rate, and recycle rate were calculated from the dilution curve shown in Figure 1 , using the method described by White et al. (1969). Figure 2 depicts the representative transition of atom percent excess of ${ }^{15} \mathrm{~N}$ (panel A) and ${ }^{13} \mathrm{C}$ (panel B) urea in plasma after the injection of the isotopes. The urea pool size, irreversible loss rate, and recycle rate were calculated from the dilution curve shown in Figure 2, using the method described by Nolan and Leng (1974). ${ }^{13} \mathrm{C}$-Urea is removed from the blood by catabolism, recycling, or secretion. ${ }^{15} \mathrm{~N}$-Urea is also removed these ways but the $\mathrm{N}$ can be recycled back into urea. Thus, the difference represents $\mathrm{N}$ recycling.

\section{Statistical Analyses}

The data are expressed as the mean \pm SEM, and were analyzed by the new Duncan's test following ANOVA and the level of protection was set at $P<0.05$. The data were analyzed using ANOVA in completely randomized design $(\mathrm{n}=15)$ with 3 treatments. The new Duncan's test was used to compare differences among groups of different ages.

\section{RESULTS}

The levels of the plasma metabolites are shown in Table 2. The levels of NEFA, $\alpha$-amino-N, and urea-N significantly increased with age as well as after weaning. However, the concentration of glucose was significantly higher at $13 \mathrm{wk}$ of age but lower at $24 \mathrm{wk}$ of age, relative to the other weeks. The plasma level of GH was significantly higher at 4 wk of age but lower at 24 wk of age relative to the other weeks. Plasma IGF-I levels significantly increased with age (Table 2).

Table 3 summarizes the data for glucose kinetics. The glucose pool size significantly increased with age by up to $263 \%$. However, the glucose pool size, when expressed per kilogram of BW, significantly decreased after weaning. The irreversible loss and recycle rates for labeled glucose were higher before (at 4 wk of age) than after (13 and 24 wk of age) weaning. There was no difference between the values at 13 and 24 wk of age (Table 3).

Table 4 summarizes the data for the urea-N kinetics. Although the plasma concentrations of urea gradually and significantly increased with age, the level at $24 \mathrm{wk}$ of age was higher than that for the other 2 age groups. There was a minimal difference in urea irreversible loss rates: no significant difference was detected among the $\left[{ }^{15} \mathrm{~N}\right]$ urea losses, but a significant increase in $\left[{ }^{13} \mathrm{C}\right]$ urea loss was demonstrated at $24 \mathrm{wk}$ of age. The urea recycle rate was not different between the observations taken before (4 wk of age) and after (13 wk of age) weaning, but significantly increased from 13 to 24 wk of age.

\section{DISCUSSION}

In the present study, the concentrations of plasma $\alpha$-amino- $\mathrm{N}$ and urea- $\mathrm{N}$ increased following weaning, and more so as the animals aged. This may be due to the cycling of urea between the saliva and absorption through the rumen as the rumen developed following weaning. In addition, plasma GH levels decreased, but IGF-I levels increased with age. Katoh et al. (2004a) reported that plasma concentration of GH increased in suckling calves but decreased in weaned calves after feeding. Furthermore, the area under the curve for GH significantly decreased after weaning. However, the area under the curve for IGF-I increased after weaning. These findings support the idea that plasma levels of metabolites and metabolic hormones change with aging. 

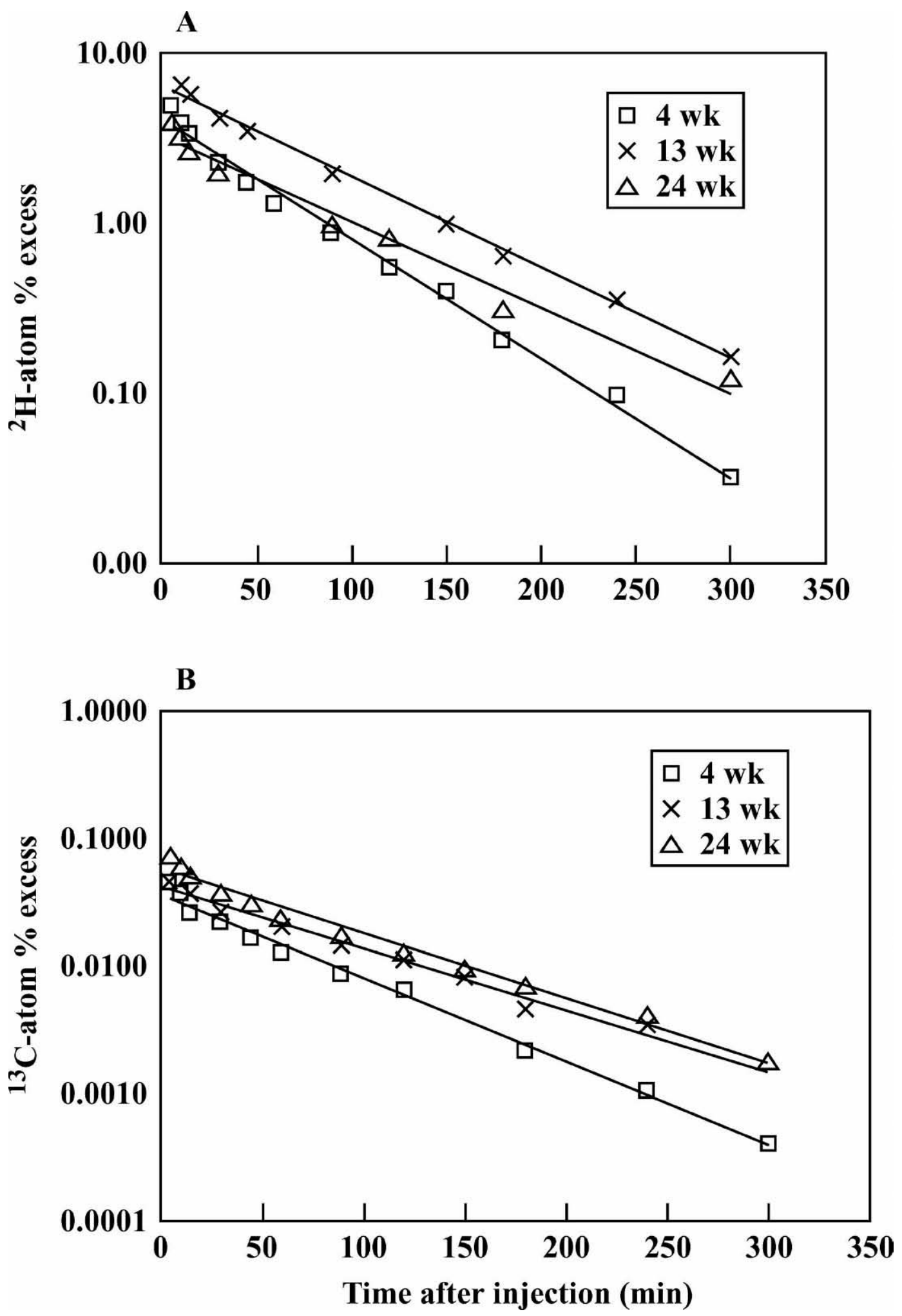

Figure 1. Representative regression curves (semilogarithmic plot against time) for the atom percent excess of ${ }^{2} \mathrm{H}$-glucose (panel A) or ${ }^{13} \mathrm{C}$-glucose (panel B) in plasma following intravenous injection of $\left[6,6-{ }^{2} \mathrm{H}\right]_{\mathrm{D}}$-glucose or $\left[\mathrm{U}_{-}{ }^{13} \mathrm{C}\right]_{\mathrm{D}}$-glucose, respectively, into calves at 4 , 13 , and 24 wk of age. 

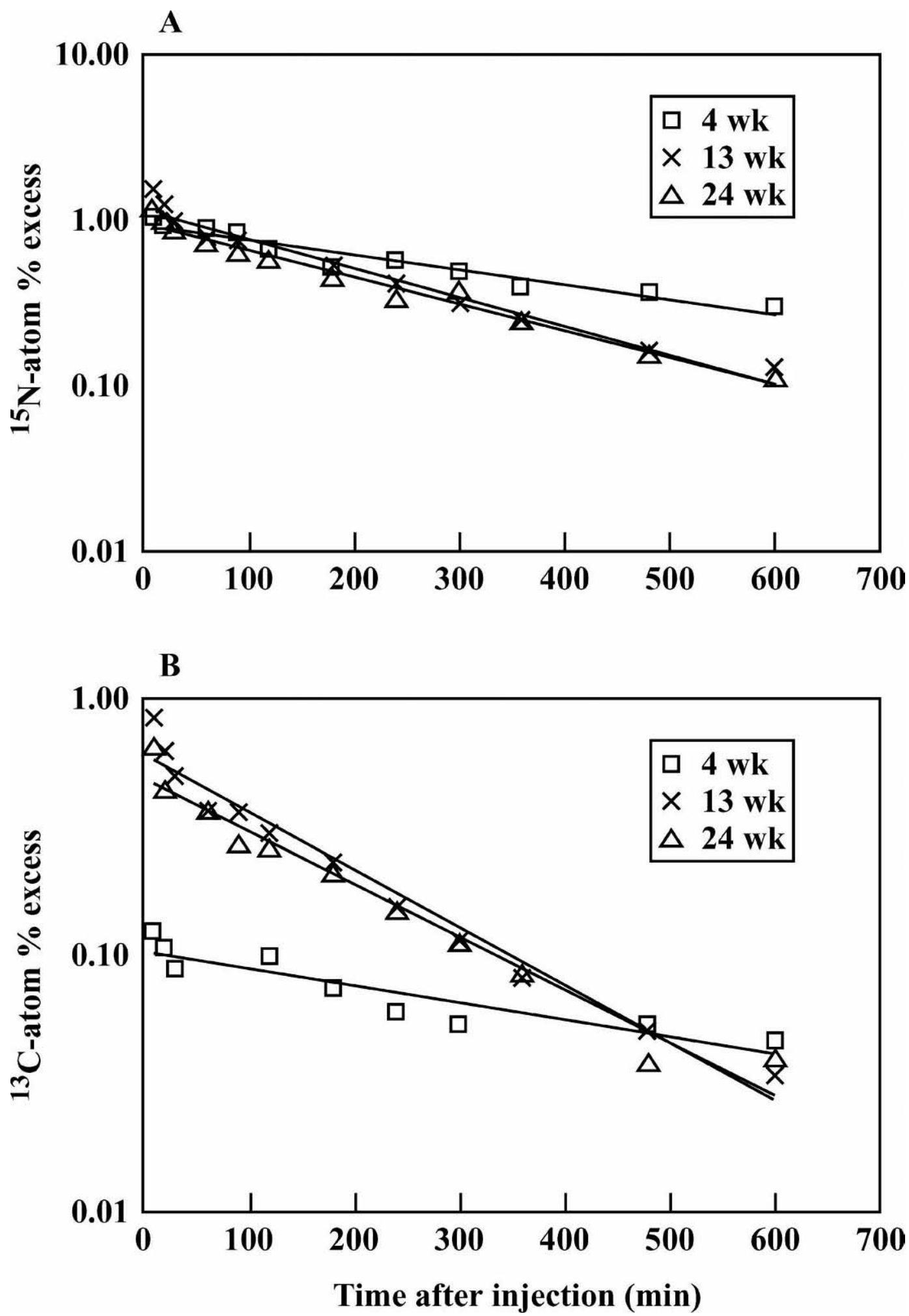

Figure 2. Representative regression curves (semilogarithmic plot against time) for the atom percent excess of ${ }^{15} \mathrm{~N}$-urea (panel $\mathrm{A}$ ) or ${ }^{13} \mathrm{C}$ urea (panel B) in plasma following intravenous injection of $\left[{ }^{15} \mathrm{~N},{ }^{15} \mathrm{~N}\right]$ urea or $\left[{ }^{13} \mathrm{C}\right]$ urea, respectively, into calves at 4,13 , and 24 wk of age. 
Table 2. Plasma concentrations (mean \pm SEM) of metabolites and metabolic hormones in calves at 4,13 , and 24 wk of age

\begin{tabular}{llrr}
\hline & $\begin{array}{l}4 \mathrm{wk} \\
(\mathrm{n}=4)\end{array}$ & $\begin{array}{l}13 \mathrm{wk} \\
(\mathrm{n}=5)\end{array}$ & \multicolumn{1}{c}{$\begin{array}{l}24 \mathrm{wk} \\
(\mathrm{n}=6)\end{array}$} \\
\hline Glucose, mg/dL & $103.1 \pm 7.5^{\mathrm{b}}$ & $115.4 \pm 3.9^{\mathrm{a}}$ & $91.6 \pm 2.2^{\mathrm{c}}$ \\
NEFA, mEq/L & $0.013 \pm 0.001^{\mathrm{c}}$ & $0.040 \pm 0.005^{\mathrm{b}}$ & $0.067 \pm 0.007^{\mathrm{a}}$ \\
$\alpha$-Amino-N, mg of N/dL & $1.99 \pm 0.09^{\mathrm{b}}$ & $3.60 \pm 0.13^{\mathrm{a}}$ & $3.89 \pm 0.21^{\mathrm{a}}$ \\
Urea-N, mg of N/dL & $3.86 \pm 0.45^{\mathrm{c}}$ & $4.77 \pm 0.28^{\mathrm{b}}$ & $7.79 \pm 0.29^{\mathrm{a}}$ \\
Growth hormone, ng/mL & $9.06 \pm 1.53^{\mathrm{a}}$ & $8.08 \pm 0.85^{\mathrm{a}}$ & $5.25 \pm 0.68^{\mathrm{b}}$ \\
IGF-I, ng/mL & $28.77 \pm 6.72^{\mathrm{c}}$ & $84.70 \pm 10.88^{\mathrm{b}}$ & $106.32 \pm 11.48^{\mathrm{a}}$ \\
\hline
\end{tabular}

${ }^{\mathrm{a}-\mathrm{c}}$ Means without common superscript letters are significantly different $(P<0.05)$.

Some studies on glucose kinetics have been reported in sheep for the adult as well as the suckling ruminant (Muramatsu et al., 1974). It is known in the adult ruminant that intraruminal infusion of sucrose (Obara and Dellow, 1993), feed intake (Young et al., 1974; Buckley et al., 1982; Russell et al., 1986), and lactation (Buckley et al., 1982) increase the pool size and irreversible loss of glucose. In the present study, the rates of irreversible loss and recycling of glucose significantly decreased with age and after weaning (Table 3). These findings suggest that glucose is preferably used as the energy source in suckling calves. In addition, as the rate of glucose recycling before weaning was significantly higher than at the other ages studied in this experiment, the glucose recycling rate may increase because of the high rate of glucose usage in suckling calves. The same may be said for the irreversible loss of glucose. It has been suggested that the amount of glucose recycled via the Cori cycle is greater before weaning than after weaning, so that glucose is mainly recycled via the Cori cycle (Dunn et al., 1967). Muramatsu et al. (1974) suggested that the lower extent of glucose recycling in the adult is due to dilution with a significant amount of nonlabeled propionate produced by the rumen microbes and from lactate formed from propionate by the rumen epithelium.

It is known that a large amount of ammonia, carbon dioxide, and methane are produced from feed proteins by the fermentation activity of the rumen microbes in ruminants. Ammonia is absorbed through the rumen wall into the portal blood stream and synthesized into urea by the liver. Urea is recycled to the rumen via saliva and across the rumen wall. Urea is an important source of $\mathrm{N}$ for the synthesis of microbial proteins; in turn, the microbes provide a supply of amino acids for the host animal after digestion and absorption in the small intestine (Abdel Rahman, 1966; Obara et al., 1991). Therefore, it is thought that recycling of urea increases with development of the rumen. In this study, we demonstrated that both $\left[{ }^{13} \mathrm{C}\right]$ urea irreversible loss and urea recycling did not change around weaning, but were significantly higher at 24 wk of age than at 3 and 13 wk of age. Furthermore, the total VFA concentration in rumen contents was significantly higher at $24 \mathrm{wk}$ than at 13 wk ( 13 wk: $34.7 \pm 1.2 \mathrm{mM} ; 24$ wk: $111.8 \pm$ $7.5 \mathrm{~m} M ; P<0.001)$. This novel finding suggests that urea irreversible loss and recycling rates gradually increase with age as well as with the development of the reticulorumen in calves. Moreover, the results of this study suggest that development of the function of the reticulorumen in calves is established at $24 \mathrm{wk}$ of age, not at $13 \mathrm{wk}$.

The urea-N pool and irreversible loss rates were increased by intraruminal infusion of urea, but not by the infusion of glucose, in sheep fed chopped lucerne hay (Obara and Dellow, 1993). These parameters have been shown to increase with increasing serum urea level (Ide, 1975; Obara and Shimbayashi, 1980) as well as with feed intake (Sarraseca et al., 1998).

Table 3. Plasma glucose kinetics (mean \pm SEM) in calves at 4,13 , and 24 wk of age

\begin{tabular}{|c|c|c|c|}
\hline & $\begin{array}{l}4 \mathrm{wk} \\
(\mathrm{n}=4)\end{array}$ & $\begin{array}{l}13 \text { wk } \\
(\mathrm{n}=5)\end{array}$ & $\begin{array}{l}24 \mathrm{wk} \\
(\mathrm{n}=6)\end{array}$ \\
\hline $\mathrm{BW}, \mathrm{kg}$ & $48.1 \pm 1.3^{\mathrm{c}}$ & $105.6 \pm 3.1^{\mathrm{b}}$ & $190.0 \pm 4.6^{\mathrm{a}}$ \\
\hline Glucose pool size, $\mathrm{g}$ & $22.78 \pm 1.08^{\mathrm{c}}$ & $37.15 \pm 3.11^{\mathrm{b}}$ & $59.93 \pm 3.48^{\mathrm{a}}$ \\
\hline Glucose irreversible loss rate, $\mathrm{mg} / \mathrm{min}$ per $\mathrm{kg}$ of $\mathrm{BW}$ & & & \\
\hline $\mathrm{U}-{ }^{13} \mathrm{C}$-glucose & $14.18 \pm 2.40^{\mathrm{a}}$ & $8.94 \pm 0.81^{b}$ & $8.73 \pm 0.48^{b}$ \\
\hline $6,6-{ }^{2} \mathrm{H}_{2}$-glucose & $16.64 \pm 3.14^{\mathrm{a}}$ & $9.01 \pm 0.99^{b}$ & $8.93 \pm 0.47^{b}$ \\
\hline $\begin{array}{l}\text { Glucose recycle rate, } \\
\mathrm{mg} / \mathrm{min} \text { per } \mathrm{kg} \text { of } \mathrm{BW}\end{array}$ & $2.46 \pm 1.741^{\mathrm{a}}$ & $0.07 \pm 0.39^{b}$ & $0.21 \pm 0.24^{\mathrm{b}}$ \\
\hline
\end{tabular}

${ }^{\mathrm{a}-c}$ Means without common superscript letters are significantly different $(P<0.05)$. 
Table 4. Plasma urea kinetics (mean \pm SEM) in calves at 4,13 , and 24 wk of age

\begin{tabular}{|c|c|c|c|}
\hline & $\begin{array}{l}4 \mathrm{wk} \\
(\mathrm{n}=4)\end{array}$ & $\begin{array}{l}13 \text { wk } \\
(\mathrm{n}=5)\end{array}$ & $\begin{array}{l}24 \mathrm{wk} \\
(\mathrm{n}=6)\end{array}$ \\
\hline Urea-N level, mg of N/dL & $3.86 \pm 0.45^{\mathrm{c}}$ & $4.77 \pm 0.28^{\mathrm{b}}$ & $7.79 \pm 0.29^{\mathrm{a}}$ \\
\hline Urea pool size, $\mathrm{g}$ of $\mathrm{N}$ & $1.49 \pm 0.32^{\mathrm{b}}$ & $1.32 \pm 0.30^{\mathrm{b}}$ & $3.89 \pm 0.15^{\mathrm{a}}$ \\
\hline \multicolumn{4}{|l|}{ Urea irreversible loss rate, $\mathrm{mg}$ of $\mathrm{N} / \mathrm{min}$ per $\mathrm{kg}$ of $\mathrm{BW}$} \\
\hline${ }^{15} \mathrm{~N}-$ Urea & $0.199 \pm 0.03$ & $0.178 \pm 0.039$ & $0.236 \pm 0.015$ \\
\hline${ }^{13} \mathrm{C}$-Urea & $0.213 \pm 0.066^{\mathrm{b}}$ & $0.199 \pm 0.054^{\mathrm{b}}$ & $0.472 \pm 0.065^{\circ}$ \\
\hline $\begin{array}{l}\text { Urea recycle rate, } \\
\mathrm{mg} \text { of } \mathrm{N} / \mathrm{min} \text { per } \mathrm{kg} \text { of } \mathrm{BW}\end{array}$ & $0.014 \pm 0.043^{\mathrm{b}}$ & $0.021 \pm 0.018^{\mathrm{b}}$ & $0.236 \pm 0.069^{2}$ \\
\hline
\end{tabular}

${ }^{\mathrm{a}-\mathrm{c}}$ Means without common superscript letters are significantly different $(P<0.05)$.

\section{CONCLUSIONS}

The results in the present study indicate that there is a difference in the development of the kinetics for glucose and urea in the developing ruminant postweaning. It is likely that weaning is the crucial moment for the change in glucose kinetics, but not necessarily for the change in urea kinetics.

\section{ACKNOWLEDGMENTS}

We gratefully acknowledge M. T. Rose (University of Wales, UK) for his contribution in preparation of the manuscript; A. F. Parlow for antibodies of ovine $\mathrm{GH}$ and IGF-I provided by National Institute of Diabetes and Digestive and Kidney Diseases (Bethesda, MD); and S. Oda (University of Iwate, Japan) and Y. Takahashi (National Institute of Animal Health, Tsukuba, Japan) for measurement of the stable isotopes.

\section{REFERENCES}

Abdel Rahman, S. 1966. Comparative study of the urease in the rumen wall and rumen content. Nature 209:618-619.

Agriculture, Forestry and Fisheries Research Council (AFFRC) Secretariat. 1999. Japanese Feeding Standard for Dairy Cattle. Japan Livestock Industry Association, Tokyo, Japan.

Annison, E., and D. Armstrong. 1969. Volatile fatty acid metabolism and energy supply. Pages 422-436 in Physiology of Digestion and Metabolism in the Ruminant. A. T. Phillipson, ed. Oriel Press, Newcastle upon Tyne, UK.

Buckley, B. A., J. H. Herbein, and J. W. Young. 1982. Glucose kinetics in lactating and nonlactating dairy goats. J. Dairy Sci. 65:371384.

Dunn, A., M. Chenoweth, and L. D. Schaeffer. 1967. Estimation of glucose turnover and the Cori cycle using glucose-6-t-14C. Biochemistry 6:6-11.

Hayashi, H., T. Yonezawa, T. Kanetani, K. Katoh, and Y. Obara. 2004. Expression of mRNA for nutrient transporters in the gastrointestinal tract before and after weaning. J. Anim. Feed Sci. 13(Suppl. 1):405-408.

Hayashi, H., T. Yonezawa, T. Kanetani, F. Terada, K. Katoh, and Y. Obara. 2005. Expression of mRNA for sodium-glucose transporter 1 and fatty acid translocase in the ruminant gastrointestinal tract before and after weaning. Anim. Sci. J. 76:339-344.

Huntington, G. B., and P. J. Reynolds. 1986. Net absorption of glucose, L-lactate, volatile fatty acids, and nitrogenous compounds by bovine given abomasal infusions of starch or glucose. J. Dairy Sci. $69: 2428-2436$.
Ide, Y. 1975. Quantitative aspect of the endogenous urea cycle in goats. Nippon Juigaku Zasshi 37:327-333.

Katoh, K., G. Furukawa, K. Kitade, N. Katsumata, Y. Kobayashi, and Y. Obara. 2004a. Postprandial changes in plasma GH and insulin concentrations, and responses to stimulation with $\mathrm{GH}$ releasing hormone (GHRH) and GHRP-6 in calves around weaning. J. Endocrinol. 183:497-505.

Katoh, K., A. Matsuda, A. Ishigami, S. Yonekura, H. Ishiwata, C. Chen, and Y. Obara. 2004b. Suppressing effects of bisphenol A on the secretory function of ovine anterior pituitary cells. Cell Biol. Int. 28:463-469.

Kitade, K., K. Takahashi, S. Yonekura, N. Katsumata, G. Furukawa, S. Ohsuga, T. Nishita, K. Katoh, and Y. Obara. 2002. Effects of nutritional conditions around weaning on carbonic anhydrase activity in the parotid gland and ruminal and abomasal epithelia of Holstein calves. J. Comp. Physiol. B 172:379-385.

Lee, Y., and T. Takahashi. 1966. An improved colorimetric determination of amino acids with the use of ninhydrin. Anal. Biochem. 14:71-77.

Muramatsu, M., M. Sugawara, S. Sasaki, K. Ambo, and T. Tsuda. 1974. Changes in the rates of recycling and turnover of glucose during development of sheep. Agric. Biol. Chem. 38:259-265.

Nolan, J. V., and R. A. Leng. 1974. Isotope techniques for studying the dynamics of nitrogen metabolism in ruminants. Proc. Nutr. Soc. $33: 1-8$

Obara, Y., and D. W. Dellow. 1993. Effects of intraruminal infusions of urea, sucrose or urea plus sucrose on plasma urea and glucose kinetics in sheep fed chopped Lucerne hay. J. Agric. Sci. 124:125-130.

Obara, Y., and D. W. Dellow. 1994. Influence of energy supplementation on nitrogen kinetics in the rumen and urea metabolism. J. Agric. Res. Q. 28:143-149.

Obara, Y., D. W. Dellow, and J. V. Nolan. 1991. The Influence of energy-rich supplements on nitrogen kinetics in the ruminants. Pages 515-539 in Physiological Aspects of Digestion and Metabolism in Ruminants. T. Tsuda, ed. Academic Press, San Diego, CA.

Obara, Y., and K. Shimbayashi. 1980. The appearance of re-cycled urea in the digestive tract of goats during the final third of a once daily feeding of a low-protein ration. Br. J. Nutr. 44:295-305.

Rose, M. T., Y. Obara, H. Fuse, F. Itoh, A. Ozawa, Y. Takahashi, K. Hodate, and S. Ohashi. 1996. Effect of growth hormone-releasing factor on the response to insulin of cows during early and late lactation. J. Dairy Sci. 79:1734-1745.

Russell, R. W., L. Moss, S. P. Schmidt, and J. W. Young. 1986. Effects of body size on kinetics of glucose metabolism and on nitrogen balance in growing cattle. J. Nutr. 116:2229-2243.

Sakurai, K., S. Ohkura, S. Matsuyama, K. Katoh, Y. Obara, and H. Okamura. 2004. Body growth and plasma concentrations of metabolites and metabolic hormones during the pubertal period in female Shiba goats. J. Reprod. Dev. 50:197-205. [Au: 1990 in text; please verify and correct]

Sano, H., T. Fujita, M. Murakami, and A. Shiga. 1996. Stimulative effect of epinephrine on glucose production and utilization rates 
in sheep using a stable isotope. Domest. Anim. Endocrinol. 13:445-451.

Sarraseca, A., E. Milne, M. J. Metcalf, and G. E. Lobley. 1998. Urea recycling in sheep: Effects of intake. Br. J. Nutr. 79:79-88.

Sasaki, Y. 1968. Development salivary secretion and the metabolic activity of the parotid gland in young calves. Jpn. J. Zootech. Sci. 39:368-376.

Sutoh, M., Y. Obara, and T. Yoneyama. 1993. The effects of feeding regimen and dietary sucrose supplementation on natural abundance of ${ }^{15} \mathrm{~N}$ in some components of ruminal fluid and plasma of sheep. J. Anim. Sci. 71:226-231.

Sutton, J. D., I. C. Hart, S. V. Morant, E. Schuller, and A. D. Simmonds. 1988. Feeding frequency for lactating cows: Diurnal patterns of hormones and metabolites in peripheral blood in relation to milk-fat concentration. Br. J. Nutr. 60:265-274.
White, R. G., J. W. Steel, R. A. Leng, and J. R. Luick. 1969. Evaluation of three isotope-dilution techniques for studying the kinetics of glucose metabolism in sheep. Biochem. J. 114:203-214.

Wiecko, J., and W. R. Sherman. 1976. Boro-acetylation of carbohydrates. Correlation between structure and mass spectral behavior in monoacetylhexose cyclic boronic esters. J. Am. Chem. Soc. 98:7631.

Wolff, J. E., and E. N. Bergman. 1972. Gluconeogenesis from plasma amino acids in fed sheep. Am. J. Physiol. 223:455-460.

Yonekura, S., K. Kitade, G. Furukawa, K. Takahashi, N. Katsumata, K. Katoh, and Y. Obara. 2002. Effects of aging and weaning on mRNA expression of leptin and CCK receptors in the calf rumen and abomasum. Domest. Anim. Endocrinol. 22:25-35.

Young, J. W., D. R. Trott, P. J. Berger, S. P. Schmidt, and J. A. Smith. 1974. Gluconeogenesis in ruminants: Glucose kinetic parameters in calves under standardized conditions. J. Nutr. 104:1049-1055. 